14 Peto R, Pike MC, Armitage P, et al. Design and analysis of randomised clinical trials requiring prolonged observation of each patient. II. Analysis and examples. Br f Cancer 1977;35:1-39. 15 Ho M. Virus infections after transplantation in man. Brief review. Arch V'irol 1977;55: 1-24. 16 Hamilton JD. Cytomegalovirus infection in renal allograft recipients. In: Melnick JL, ed. Monographs in virologv. Basle: Karger, 1982:31-46.

Patel R. Fiala M, Berne V, Chatterice N. Cytomegalovirus infections in renal allograft recipients: correlative studies with histocompatibility antigens. NZ Med f 1978;87:393-4

18 Olding LB, Jensen FC, Oldstone MBA. Pathogenesis of cytomegalovirus infection. I. Activation of virus from bone marrow-derived lymphocytes by in vitro allogenic reaction. 7 Exp Med 1975;141:561-72

19 Hendriks GFJ, Schreuder GMT, Claas FHJ, et al. HLA-DRw6 and renal allograft rejection. Br.Med 7 1983;286:85-7.

20 Soulillou JP, Bignon JD. Poor kidney-graft survival in recipients with HLA-DRw6. N Englf Med 1983;308:969-70
21 Diosi P, Arcan P, Plavosin L. Genetic control of resistance to mouse cytomegalovirus infection. rch Geschwulstforsch 1974:44:23-7.

22 Chalmer JE, Mackenzic JS, Stanley NF. Resistance to murine cytomegalovirus linked to the major histocompatibility complex of the mouse. I Gen Virol 1977;37:107-14

23 Grundy JE, Mackenzic JS, Stanley NF. Influence of $\mathrm{H}_{2}$ and non- $\mathrm{H}_{2}$ genes on resistance to murine cytomegalovirus-infection. Infect Immun 1981:32:277-86.

24 Berk EJ Jr. Thorsby $\mathrm{E}$. Both DR and MT class II HLA molecules may restrict proliferative T lymphocyte responses to antigen. Scand $f$ Immunol 1982;16:543-7.

25 Tsuii Nose Y, Inouve Komori K, Yamamura M. HLA-D DR linked immune response to Candid allergen: an in vivo and in vitro study in Japanese. Tokai $\mathcal{F}$ Exp Clin Med 1981;6:113-20.

26 Lopez C, Simmons RL, Mauer SM, Najarian JS, Good RA. Association of renal allograft rejection with virus infections. Am F Med 1974;56:280-9.

Accepted 25 May 1985

\title{
Lack of relation between glycosylated haemoglobin concentrations and number of daily insulin injections: cross sectional study in care of ambulatory diabetes
}

\author{
CARL-DAVID AGARDH， GUSTAV TALLROTH
}

\begin{abstract}
Diabetic treatment aims at achieving a normal blood glucose concentration as reflected by the glycosylated haemoglobin concentration. Intensive treatment by insulin pump or multiple insulin injections is thought to achieve this. In an unselected group of outpatient diabetics metabolic control was the same after one, two, three, or more injections, which suggests that the mode of treatment was optimal for each group.
\end{abstract}

\section{Introduction}

Evidence of a relation between the degree of glycaemic control and development of late complications in diabetes is increasing. Thus the aim of diabetic treatment is to achieve as normal blood glucose concentrations, reflected by glycosylated haemoglobin concentrations, as possible. Recent studies have shown that intensive treatment, by either insulin pump " or multiple insulin injections, can achieve this goal. This study aimed at determining any relation between the degree of metabolic control and the number of insulin injections given a day in an unselected group of outpatient diabetics.

\section{Patients, methods, and results}

The study included 289 consecutive diabetics treated with insulin who were attending an outpatient clinic. The glycosylated haemoglobin concentration was determined by ion exchange chromatography with microcolumns (BIO-RAD)

The patients were divided into groups according to the number of insulin injections given a day: group A received one injection early in the morning; group $\mathrm{B}$ two a day, in the morning and at $4-5 \mathrm{pm}$; group $\mathrm{C}$ two a day, in the morning and at $9-10 \mathrm{pm}$; and group D three or more a day

The table shows no difference in glycosvlated haemoglobin concentrations between the four groups regardless of the number of insulin injections given a day. No correlation existed between glycosylated haemoglobin concentration and age, age at onset, duration of diabetes, amount of insulin given a day (IU $/ \mathrm{kg}$ ), or body mass index in any of the groups (data not shown). To ensure that the results were not influenced by the type of diabetes, the patients were also divided into groups according to age at onset of diabetes. Patients aged under 30 at onset were considered to have type I diabetes and those over 30 type II diabetes. The table shows no differences between the groups in either type I or type II diabetics. Furthermore, within each group the age at onset did not significantly influence the degree of metabolic control when expressed as glycosylated haemoglobin concentration.

Department of Internal Medicine, University of Lund, S-221 85 Lund, Sweden CARL-DAVID AGARDH, MD, PHD, associate professor GUSTAV TALLROTH, $M$ D, resident doctor

Correspondence to: Professor Carl-David Agardh
Mean SEM percentages of glycosylated haemoglobin concentrations in four groups of diabetics

\begin{tabular}{|c|c|c|c|}
\hline Groups & All patients & Patients aged under 30 at onset & Patients aged over 30 at onset \\
\hline A & $7.8(0.2) \mathrm{n}=67$ & $8 \cdot 10 \cdot 3)(n=28$ & $7 \cdot 60 \cdot 2)(n=39$ \\
\hline B & $8 \cdot 30 \cdot \mathrm{n}=133$ & $8 \cdot 3(0 \cdot 1) \mathbf{n}-88$ & $8 \cdot 1(0-2) n-45)$ \\
\hline C & $8 \cdot 3 \cdot 0 \cdot 2, n=36$ & $8 \cdot 2(0.3) n-28$ & $8.5(0.3) \mathrm{n}=8)$ \\
\hline $\mathrm{D}$ & $8 \cdot 20 \cdot 2 \quad \mathrm{n}=53$ & $8 \cdot 30 \cdot 2)(n=43$ & $7.5(0.5)(n-10)$ \\
\hline
\end{tabular}

Student's $t$ test

\section{Discussion}

Recently several studies have shown that intensified insulin treatment, by either multiple insulin injections ${ }^{3}$ or subcutaneous insulin infusion systems, ${ }^{12}$ gives normal or near normal glycosylated haemoglobin concentrations in selected groups of patients. In most studies, however, intensive engagement of the physicians might be as important a factor as the mode of treatment. Thus in everyday practice the question remains of whether metabolic control of diabetes improves with the number of insulin injections given a day in an unselected group of outpatient diabetics.

In this study, regardless of whether the patients received one, two, three, or more injections a day, the degree of metabolic control was the same. In our opinion this reflects the fact that the mode of treatment was optimal for each group. The study does not tell whether further improvement might have been achieved if patients given one or two injections a day had been given more intensive treatment. On the other hand, as the glycosylated haemoglobin concentration was the same in all four groups the number of insulin injections per se does not seem to be the most important factor to improve metabolic control. Other factors, such as intensive attention by the health care team and the patients' self control of blood glucose concentrations, might be just as important. ${ }^{+5}$ The conflicting results between this and other studies showing improved metabolic control with multiple insulin injections may show this.

\section{References}

1 Pickup JC, White MC, Keen H, Parsons JA, Alberti KGMM. Long-term continuous subcutaneous insulin infusion in diabetics at home. Lancet 1979;ii: 870 -3.

2 Tamborlane WV, Puklin JE, Bergman M, et al. Long-term improvement of metabolic control with the insulin pump does not reverse diabetic microangiopathy. Diabetes Care 1982;5(suppl 1) $58-64$

3 Schiffrin A, Belmonte MM. Comparison between continuous subcutaneous insulin infusion and multiple injections of insulin. A one-year prospective study. Diabetes 1982;31:255-64

4 Schiffrin A, Belmonte M. Multiple daily self-glucose monitoring: its essential role in long-term glucose control in insulin-dependent diabetic patients treated with pump and multiple subcutaneous injections. Diabetes Care 1982;5:479-84.

5 Worth R, Home PD, Johnston DG, et al. Intensive attention improves glycaemic control in insulindependent diabetes without further advantage from home blood glucose monitoring: results of a controtled trial. Br Med f 1982;285:1233-40.

(Accepted 6 fune 1985) 